\title{
The Macroeconomic Fallout of Shutting Down the Banking System
}

By Qian Chen, Christoffer Koch, Gary Richardson, and Padma Sharma

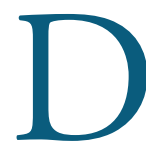

uring the 2008-09 financial crisis, the U.S. government acted quickly to prevent the commercial banking system from shutting down. Policymakers arranged bailouts of major banks to prevent a suspension of bank deposits, where banks cease paying checks and refuse depositors' requests to withdraw funds. These bailouts helped the United States avoid a kind of financial paralysis in which firms are unable to pay workers and households cannot pay for goods and services. However, since 2008, many policymakers and private citizens have debated the wisdom of bank bailouts, citing potential moral hazard concerns as well as the high cost to taxpayers.

Crucial to this debate is an accurate assessment of the costs and benefits of preventing a suspension of bank deposits, which can be difficult to determine. Prevention costs, for example, go beyond bailout spending in moments of crisis. Preventing deposit suspensions also involves significant spending on the ongoing operations of regulatory agencies, which can amount to billions of dollars each year. Benefits can be even

Qian Chen is an assistant professor at the Beijing Technology and Business University. Christoffer Koch is a senior economist at the Federal Reserve Bank of Dallas. Gary Richardson is a professor at the University of California, Irvine and an affiliate at the National Bureau of Economic Research. Padma Sharma is an economist at the Federal Reserve Bank of Kansas City. This article is on the bank's website at www. KansasCityFed.org 
more challenging to determine with precision, as policymakers cannot directly observe the loss to economic activity that might have occurred if they had allowed the banking system to shut down. Although past experiences with national payment suspensions can provide insight into potential losses, they likely have limited relevance, as nationwide bank suspensions have not occurred since the Great Depression.

One way to circumvent these challenges is to study the effects of more recent deposit suspensions that occurred at the state level. In this article, we study the effects of deposit suspensions in Nebraska in 1983, Ohio and Maryland in 1985, and Rhode Island in 1991. We find that the effect of the suspensions varied by the phase of the business cycle as well as the duration and magnitude of the suspensions. In Rhode Island, which underwent a long and complete deposit suspension in a recession, the suspension persistently lowered employment, gross state product, and per capita personal income. In contrast, in Maryland, Nebraska, and Ohio-states that experienced relatively short and partial suspensions during economic expansions—-suspensions had little measurable effect on macroeconomic aggregates. Our results suggest that interventions that prevent large deposit suspensions during recessions, such as those undertaken after 2008, are likely worth the costs. Effective interventions not only help avoid economic losses during recessions, but also prevent losses to output and employment several years into the future.

Section I reviews the causes of the four state deposit suspensions. Section II summarizes the effect of deposit suspensions on macroeconomic aggregates in each of the four states. Section III discusses the lessons from the four state suspensions and their implications for evaluating interventions during the global financial crisis.

\section{The Causes of Bank Deposit Suspensions}

Historically, policymakers have suspended deposits - that is, temporarily prohibited depositors from withdrawing their funds- to prevent bank runs. Bank runs deplete banks' resources and can trigger bank failures if left unchecked. In the Great Depression, for example, depositors grew concerned about the safety of their funds and withdrew them simultaneously, jeopardizing the stability of thousands of banks and prompting deposit suspensions (Richardson 2013). To 
prevent the recurrence of pervasive bank runs and to reassure depositors of the safety of their funds in the banking system, Congress established the Federal Deposit Insurance Corporation (FDIC) in 1933 and the Federal Savings and Loans Insurance Corporation (FSLIC) in 1934. Both institutions provided a government guarantee to protect the value of deposits up to $\$ 5,000$ and were responsible for disposing of the assets and liabilities of failed banks. ${ }^{1}$

These regulatory reforms did not end bank runs entirely. Although the FDIC and FLSIC insured a significant share of deposits made at banks with federal charters, many banks chartered at the state level did not have these protections and were instead insured by state-level private deposit insurers. Because state-insured banks were outside the supervisory purview of federal agencies, the Federal Reserve, the FDIC, and the FSLIC could not take preemptive actions to prevent bank failures or support the financial system with a liquidity backstop. Instead, state-insured banks were subject to regulation by state regulators, who lacked resources and specialized skills to handle institutions in distress (English 1993). Indeed, difficulties at state-level insurers led directly to bank runs in Maryland, Nebraska, Ohio, and Rhode Island from 1983 to 1991. In each state, the failure of a single large financial institution due to mismanagement and malfeasance threatened the solvency of the state insurance fund. ${ }^{2}$ News about these failures frightened depositors, who feared for the safety of their deposits in other institutions covered by the distressed insurers and rushed to withdraw their funds. When these bank runs reached healthy depository institutions, the governors of all four states suspended deposits.

The failure of mismanaged institutions was merely a catalyst for the failure of state deposit insurers, which had deep-rooted weaknesses. State-level insurance systems collected premiums from their member banks that were too low relative to the risk they insured. Furthermore, the insurer' members were predominantly inadequately regulated institutions with weak risk-management practices and thereby posed a risk to the solvency of the insurance fund (English 1993). Poorly managed state-insured institutions and insufficiently funded insurance in the four states eroded depositors' confidence in the insurers. This loss of public trust made the banking systems vulnerable to bank runs-and, therefore, subject to deposit suspensions. 
After the four states suspended deposits, the FDIC, FSLIC, and Federal Reserve took steps to minimize the severity and duration of the ensuing economic shock. The FDIC and FSLIC accelerated the process of transitioning state-insured institutions in Ohio, Maryland, and Rhode Island to federal insurance. The Federal Reserve rerouted all automated clearinghouse $(\mathrm{ACH})$ payments in Rhode Island to federally insured institutions and relaxed restrictions on mortgage lending to keep payments and credit flowing. State-insured banks in Ohio and Maryland received substantial advances from the Federal Reserve's discount window, and the Federal Reserve Bank of Boston stood prepared to make advances to Rhode Island's state-insured institutions (Todd 1994). These interventions allowed depositors to access incoming funds and obtain new credit, but depositors were still unable to withdraw previously deposited funds from their accounts.

Although the four state deposit suspensions had similar causes, they occurred in very different economic environments. In Chen and others (2020), we compile data on of each of the four deposit suspensions and their macroeconomic consequences. Table 1 summarizes key differences across the four episodes. A fundamental difference across the four states was the phase of the business cycle in which they suspended deposits, as measured by per capita personal income. Rhode Island was the only state to suspend deposits during an economic contraction: per capita personal income declined by 1.85 percent on average in the four quarters prior to the onset of the payments suspension. The remaining three states suspended deposits during economic expansions: per capita personal income grew in Maryland, Nebraska, and Ohio prior to the suspensions.

A second difference across states was the extent of the deposit suspensions. The suspension in Rhode Island was complete: depositors did not have access to any of their deposits until institutions were reopened or payouts were made to depositors by a state government agency. ${ }^{3}$ In contrast, suspensions in the remaining three states were partial. Depositors in Maryland and Ohio were permitted to withdraw up to $\$ 1,000$ and $\$ 750$ a month, respectively. In Nebraska, depositors retained access to their checking accounts but could not withdraw certificates of deposit until maturity. ${ }^{4}$ Table 1 shows that the value of suspended deposits was substantially larger in Rhode Island and 


\section{Table 1}

State-Level Suspensions of Bank Payments, 1983-91

\begin{tabular}{|c|c|c|c|c|c|c|}
\hline \multirow[b]{2}{*}{ State } & \multicolumn{2}{|c|}{ Insured institutions } & \multicolumn{2}{|c|}{ Date of failure } & \multirow{2}{*}{$\begin{array}{c}\text { Percent growth } \\
\text { in per capita } \\
\text { personal income } \\
\text { (four-quarter average) }\end{array}$} & \multirow{2}{*}{$\begin{array}{c}\text { Deposits per } \\
\text { household as a } \\
\text { percentage of median } \\
\text { household income }\end{array}$} \\
\hline & Type & Number & Year & Month & & \\
\hline Maryland & SL & 102 & 1985 & May & 2.37 & 19.1 \\
\hline Nebraska & T, CU, SL & 60 & 1983 & Nov. & 5.38 & 5.7 \\
\hline Ohio & SL & 70 & 1985 & March & 3.39 & 3.1 \\
\hline Rhode Island & $\mathrm{B}, \mathrm{CU}, \mathrm{SL}$ & 45 & 1991 & Jan. & -1.85 & 13.9 \\
\hline
\end{tabular}

Notes: In the column "Type" under "Insured Institutions," B indicates banks, T indicates trust companies, and $\mathrm{CU}$ indicates credit unions and cooperative credit corporations. SL indicates savings and loans and similar thrifts, including building and loans, mutual savings banks, and industrial loan and investment companies.

Sources: Todd (1994), House of Representatives (1991), Wood (1992), Nebraska (1984), and Bureau of Economic Analysis (Haver Analytics).

Maryland than in Ohio and Nebraska. In Rhode Island and Maryland, suspended deposits represented 19 and 14 percent of median household income, respectively. In Nebraska and Ohio, these deposits represented a mere 6 and 3 percent of median household income.

Finally, the suspension lasted longer in Rhode Island than in Maryland, Ohio, and Nebraska. Rhode Island's governor suspended deposits in January 1991, and nearly three years elapsed before all depositors in the state were fully repaid. Around 50 percent of deposits were paid out or made accessible in the first six months, another 46 percent were paid out in the following year, and the remaining 4 percent were paid out in September 1993. In contrast, governments in Maryland and Ohio acted quickly to establish new deposit insurance funds within 10 days of suspending deposits to protect institutions. In Ohio, institutions eligible for FSLIC insurance were allowed to reopen within two weeks after suspensions were first imposed. ${ }^{5}$

Political factors played a substantial role in delaying the resolution of the crisis in Rhode Island. Instead of using state funds to resolve the crisis, Rhode Island's government first sought to raise funds by requesting bailouts from the federal government. Although the federal government provided a loan guarantee for Rhode Island bonds, it did not offer direct assistance. The state also filed lawsuits against failed institutions and the auditor of the state insurance fund to recover lost deposits. This strategy for raising funds required the suspension to remain in place until legislative hearings were complete and lawsuits were settled. 
Although the state obtained $\$ 103$ million in the settlement of the lawsuit against the auditor of the insurance fund, the reluctance of Rhode Island's administration to respond speedily to the crisis using its own funds resulted in a prolonged period of financial paralysis in the state (House of Representatives 1991a, 1991b; Prosky 2018).

\section{Macroeconomic Consequences of Suspensions of Bank Payments}

Deposit suspensions have the potential to generate widespread economic consequences. However, the effects of deposit suspensions likely vary based on the duration and intensity of the suspension. To account for differences in deposit suspensions across Rhode Island, Maryland, Nebraska, and Ohio, we measure the difference between actual economic outcomes in each state following the deposit suspensions and "counterfactual" outcomes-those realizations estimated to have occurred had states not suspended payments and instead used their resources to support the banking system and prevent payment disruptions.

Measuring counterfactual outcomes can be challenging. In Rhode Island, for example, estimating the counterfactual outcome means quantifying economic activity in a hypothetical parallel world in which the state did not suspend bank deposits in 1991. We estimate this hypothetical outcome by using the weighted average of economic outcomes from states that most resembled Rhode Island before suspensions in 1991. ${ }^{6}$ We refer to this subgroup of states as "control states." We similarly estimate the hypothetical economic outcomes in Maryland, Nebraska, and Ohio using the weighted average of economic outcomes in their respective control states.

The economic indicators for which we estimate counterfactuals are the unemployment rate, the labor force participation rate, employment, and output. These economic indicators broadly describe the health of an economy and represent key measures of interest to policymakers. The unemployment rate measures the share of individuals who do not have a job, are available for work, and have actively looked for work in the four weeks prior to measurement. The labor force participation rate measures the proportion of the working-age, civilian population that is either employed or actively looking for work. Employment is based on surveys of firms that report the total number of individuals on 
payrolls in their establishments. Finally, output or gross state product is the value of all final economic output produced within the state during a specific period.

Chart 1 shows differences in the paths of the unemployment rate, the labor force participation rate, employment, and gross state product in Rhode Island alongside their estimated counterfactuals. Panel A of Chart 1 shows that before the deposit suspension, the unemployment rate in Rhode Island moved in lockstep with the counterfactual from control states. However, after deposits were suspended, the two series diverged: the unemployment rate in the control states peaked in December 1991 and began to decline, while the unemployment rate in Rhode Island continued to rise until 1993. From 1993 to 2001, Rhode Island's unemployment rate declined but remained at a higher level than the counterfactual. Specifically, the unemployment rate in Rhode Island remained approximately 1 percentage point higher a decade after deposit suspensions, relative to the counterfactual.

Panels B through D of Chart 1 show that the deposit suspension in Rhode Island also are estimated to have had persistent effects on the labor force participation rate, employment, and gross state product. Panel B shows that the suspension lowered the labor force participation rate by 3 percentage points relative to control states. The effect peaked nearly four years after deposits were first suspended, and the recovery was gradual: by 2001, the labor force participation rate was still more than 1.5 percentage points lower in Rhode Island. Panel C shows that the level of employment declined steadily and substantially relative to controls. By 1994, Rhode Island had lost 40,000 more jobs than it would have absent the suspension. This decline appears to have been prolonged and possibly permanent. Finally, Panel D shows that gross state product also declined substantially in Rhode Island relative to controls. An examination of a range of other state-level series show that this result is driven by several factors, including a decline in Rhode Island's population during the 1990s counter to the experience of other East Coast states, a decline in the labor force participation rate (which was greater than in control states), and slow growth in per capita productivity relative to states that benefited from the technology and finance booms of the 1990s. 


\section{Chart 1}

Effects of Payments Suspensions in Rhode Island

Panel A: Unemployment Rates

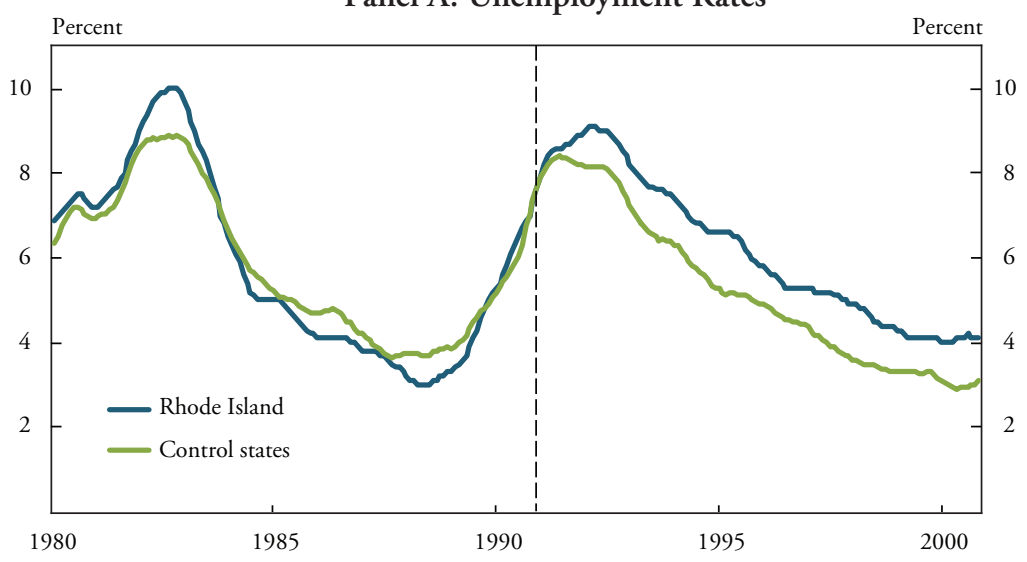

Panel B: Labor Force Participation Rate

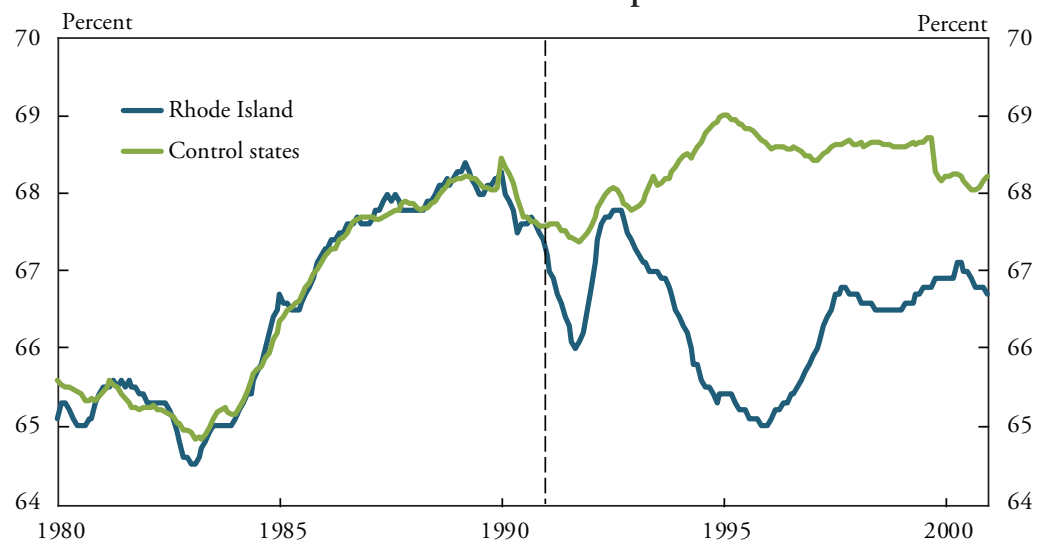

Panel C: Employment

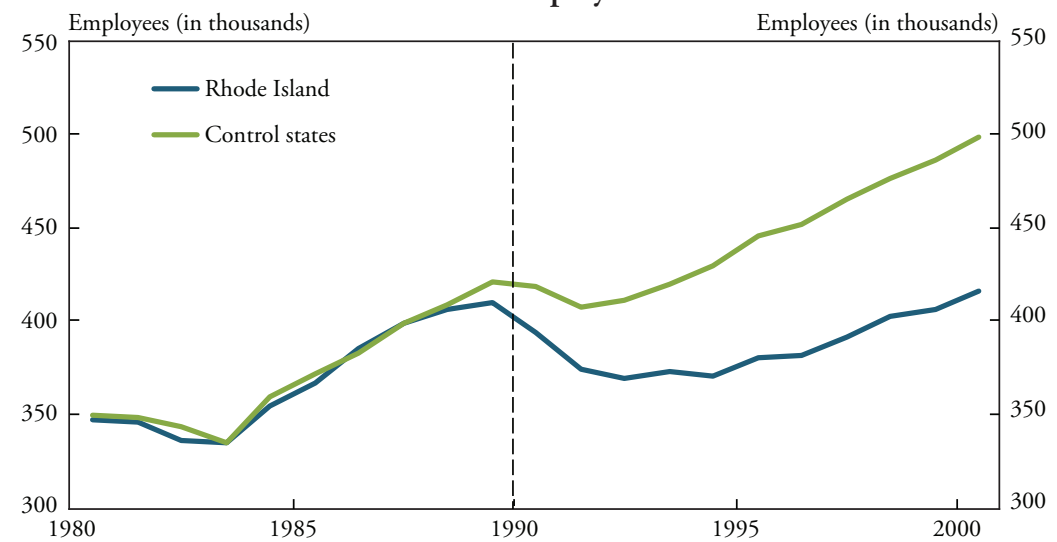




\section{Chart 1 (continued)}

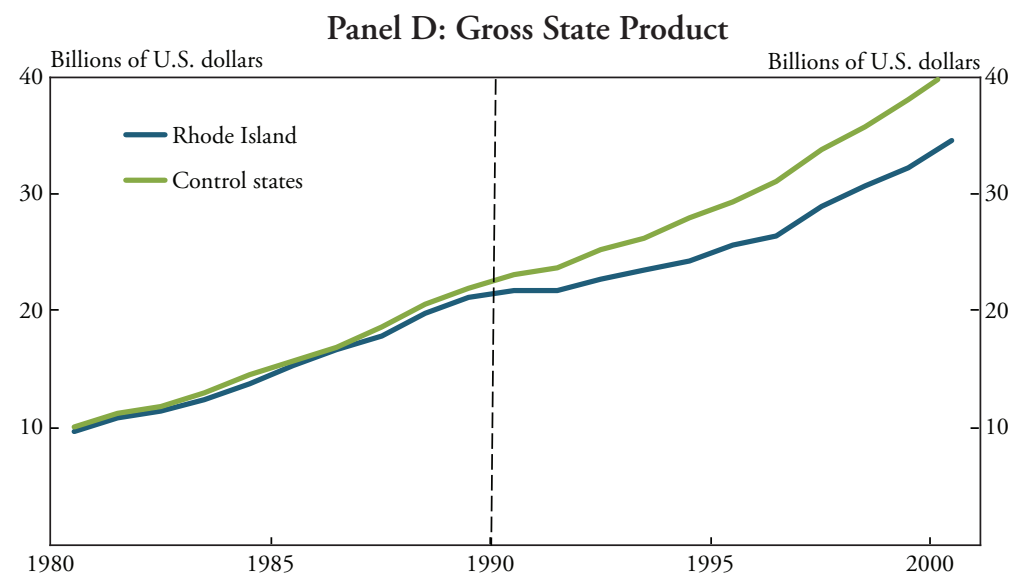

Notes: The unemployment rate and labor force participation rate in Panels A and B, respectively, are month-end measurements; the vertical line marks December 1990 and delineates the period preceding deposit suspensions in Rhode Island that took place in January 1991. Employment and gross state product in Panels C and D, respectively, are annual series; the vertical line in these charts marks the measurements for 1990.

Sources: Bureau of Labor Statistics, Bureau of Economic Analysis, and U.S. Census Bureau.

Table 2 provides quantitative support to the graphical overview by summarizing the effects of deposit suspensions on nine state-level series. For each series, the table reports the average difference between outcomes in each of the four states and their estimated counterfactuals two and five years after the suspensions. The second column indicates the direction of difference between observed and counterfactual outcomes that is characteristic of an adverse change in each series. Examples of adverse changes include an increase in the unemployment rate or a decline in output in the state that underwent deposit suspensions relative to controls.

The first row of Table 2 indicates two years after the deposit suspension, the unemployment rate in Rhode Island was on average 0.63 percentage point higher than the counterfactual. Five years after the suspension, unemployment in Rhode Island was on average 0.94 percentage point higher than in controls. Mortgage delinquency and bankruptcy filings were also higher on average in Rhode Island relative to their counterfactuals two and five years after deposits were suspended. Conversely, output, employment, the labor force participation rate, per capita personal income, population, and the CredAbility Consumer Distress Index (a measure of household financial distress) were lower on average in Rhode Island relative to the control states. ${ }^{7}$ The substantial 


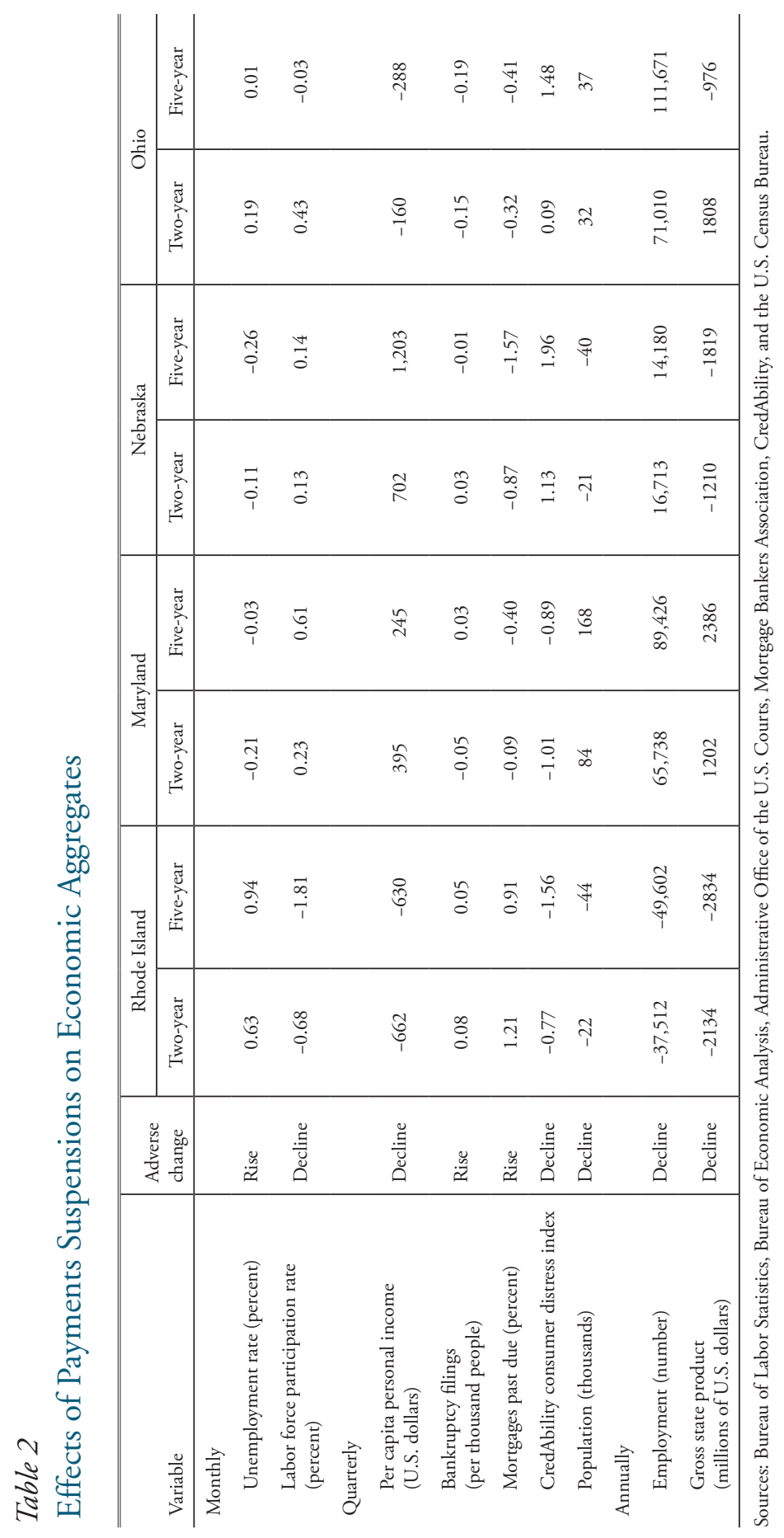


and persistent adverse effects across a broad range of economic indicators suggest that the deposit suspension in Rhode Island amplified the recessionary dynamics that were prevalent in New England at the time.

In contrast, the results for Maryland, Ohio, and Nebraska in Table 2 reveal that their deposit suspensions hardly affected the economies of those states. The effects we estimate for these states are small or are consistent with economic expansion, rather than contraction. Specifically, we find that in Maryland and Nebraska, the unemployment rate declined and per capita personal income and employment increased relative to control states. In Ohio, the unemployment rate increased and output declined over the two-year horizon, but these effects subsided after five years. Overall, we find no systematic relationship between macroeconomic aggregates and the deposit suspensions in Maryland, Ohio, and Nebraska. This result suggests that deposit suspensions accelerated recessionary dynamics but had little effect in expansionary phases of the business cycle.

\section{Lessons and Implications for the Global Financial Crisis}

In the immediate aftermath of the deposit suspension in Rhode Island, states worked to root out the institutional features that kindled the crisis. Most states made it mandatory for depository institutions to obtain federal insurance and phased out state deposit insurance systems (English 1993). By 2007, no state-level primary insurers for banks and savings associations remained. As of 2017, only 2 percent of credit unions are privately insured and outside the coverage of the National Credit Union Association (FDIC 2007; GAO 2017). These reforms make it unlikely that a future deposit suspension will arise from the failure of state-level insurance systems.

However, the financial landscape in the United States evolved from the early 1990 s to 2008 , and other vulnerabilities emerged. Banks held increasingly complex financial securities on their balance sheets, and the actual risks inherent in these products were not apparent. Moreover, the financial system became more integrated over time, exposing banks to weaknesses in institutions beyond the commercial banking sector such as investment banks and insurance companies. These vulnerabilities came to the fore during the global financial crisis of 2008-09. Our estimates 
of the effects of the payments crisis in Rhode Island offer a framework to evaluate policy responses during the global financial crisis.

The broad policy lesson from Rhode Island is that banking crises that occur in a contraction, such as the collapse of large financial services firms during the global financial crisis, require earlier and more forceful interventions. The delayed interventions in Rhode Island lengthened and deepened the contraction that the state was already experiencing. During the global financial crisis, legislative measures enacted to rescue the banking system were subject to public criticism owing to the use of taxpayer funds. Our results for the Rhode Island crisis suggest that these interventions were necessary. When Congress passed the Troubled Assets Relief Program (TARP) on September 29, 2008, allocating \$700 billion to support financial institutions, the U.S. economy had already been in contraction since the start of the year, and panic prevailed in the financial system. ${ }^{8}$ Successive, "old-fashioned" deposit runs on financial institutions posed a threat to the stability of the overall financial system (Rose 2015). For instance, Lehman Brothers' failure on September 15, 2008, triggered runs on Washington Mutual, which eventually failed on September 25, 2008. This episode led to a run on Wachovia, and within a week, the bank was out of resources to meet creditors' claims.

Policymakers' fears of deposit suspensions likely would have materialized absent interventions to check the spread of panic among depositors. Our results indicate that if deposits had been suspended during the global financial crisis, the trough of the recession in the United States would have been deeper and longer, and adverse effects on output, employment, the labor force participation rate, and bankruptcies would have persisted long after the crisis began. Timely interventions from the Federal Reserve and FDIC (in the form of TARP and the Temporary Liquidity Guarantee Program, respectively) preserved output and employment relationships that would have been lost otherwise due to the scarring effects of deposit suspensions. ${ }^{9}$ On balance, the preserved output and employment over the medium term provided by these interventions compare favorably with their cost of approximately 3.5 percent of U.S. gross domestic product in 2009 as determined by Lucas (2019). ${ }^{10}$ 


\section{Conclusion}

Interventions taken to stabilize the financial system after the 2008 financial crisis were controversial at the time due to perceived high costs to taxpayers. However, the costs of allowing the bank system to shut down may have been much higher in the longer term. We study modern episodes of state deposit suspensions to quantify the effects of shutting down the commercial banking system on aggregate economic activity. We find that the suspension in Rhode Island, which was imposed during a recession, increased unemployment and reduced output for at least 10 years after the crisis. The suspensions in Maryland, Ohio, and Nebraska, which occurred during economic expansions, did not have a measurable economic effect.

The events in Rhode Island offer a crucial lesson in safeguarding the financial system against future payments crises. Adequate regulation and supervision of depository institutions are essential in preventing deposit suspensions. In the wake of the global financial crisis, the Dodd-Frank Act introduced new regulations aimed at limiting excessive risk-taking and enhancing the resilience of the banking system. Some of these measures include stress tests, capital regulations and requirements for complex financial institutions to submit "living wills" that outline their plans for orderly dissolution in the event of a crisis. These measures not only bolster the solvency and liquidity of the depository institutions but also provide regulators with regular snapshots of the risks in bank balance sheets. The current enhanced regulatory structure helps protect the banking system against a recurrence of a crisis resembling the deposit suspension in Rhode Island or the global financial crisis. The disparate origins of Rhode Island's crisis in the 1990s and the global financial crisis two decades later underline the importance of updating regulations in line with the growing complexity of the financial landscape. 


\section{Endnotes}

${ }^{1}$ The FSLIC was closed in 1989 due to insolvency. Following the FSLIC's closure, the FDIC took over insurance of savings and loans institutions. The amount insured by the FDIC has been increased by Congress several times since its inception and is currently $\$ 250,000$ per depositor per FDIC-insured bank for each account ownership category.

${ }^{2}$ The state-level insurance funds that became insolvent were the Maryland Savings Share Insurance Corporation (MSSIC), the Nebraska Depository Insurance Guaranty Corporation (NDIGC), the Ohio Deposit Guaranty Fund (ODGF), and the Rhode Island Share and Deposit Indemnity Corporation (RISDIC). The NDIGC failed in 1983, the MSSIC and ODGF in 1985, and the RISDIC in 1991. The insurance corporations were chartered at the state level but did not have financial backing from the state government. They raised capital from the insured financial institutions, which paid premiums to the insurance fund.

${ }^{3}$ The Depositors Economic Protection Corporation, which was set up by the state government to return depositors' funds from suspended accounts, took over deposits from the RISDIC.

${ }^{4}$ The certificates of deposit were issued by industrial savings companies and were called "investment certificates."

5nstitutions had to demonstrate that they were solvent, financially stable, and able to conform to the FDIC or FSLIC's regulatory requirements to be eligible to receive insurance from either of the two agencies.

'This method, known as "synthetic control," was originally developed by Abadie and Gardeazabal (2003). In Chen and others (2020), we develop a Bayesian synthetic control method based on the earlier authors' technique. The key difference between the two is that our method offers a systematic technique to determine when a measured effect is statistically important. These inferences are still an ongoing area of research under the former method.

${ }^{7}$ The CredAbility Consumer Distress Index is a comprehensive measure of the financial condition of the average American household. A lower value is indicative of greater financial distress.

${ }^{8}$ The U.S. Treasury provided capital to banks under TARP by purchasing their preferred shares. TARP aimed to restore financial stability by bolstering banks' capital.

${ }^{9}$ Under the Temporary Liquidity Guarantee Program, the FDIC guaranteed newly issued debt by banks, thrifts, and their holding companies. This guarantee was provided to restore creditors' confidence in debt issued by financial institutions.

${ }^{10}$ Articles in the press have suggested that the government profited from TARP given net receipts from assisted financial institutions. However, Lucas (2019) concludes that the bailouts involved net costs of $\$ 500$ billion by using a fair-value approach based on the net present value of costs and payoffs incurred at the time of bailouts. Reports concluding that TARP resulted in a profit to the Treasury are based on after-the-fact accounting that Lucas argues may not be the correct approach to evaluating the program's costs and benefits. 


\section{References}

Abadie, Alberto, and Javier Gardeazabal. 2003. "The Economic Costs of Conflict: A Case Study of the Basque Country." American Economic Review, vol. 93, no. 1, pp. 113-132. Available at https://doi.org/10.1257/000282803321455188

Chen, Qian, Christoffer Koch, Gary Richardson, and Padma Sharma. 2020. "Payments Crises and Consequences." Federal Reserve Bank of Kansas City, Research Working Paper no. 20-10, September. Available at https://doi. org/10.18651/RWP2020-10

English, William B. 1993. "The Decline of Private Deposit Insurance in the United States." Carnegie-Rochester Conference Series on Public Policy, Journal of Monetary Economics, vol. 38, pp. 57-128. Available at https://doi. org/10.1016/0167-2231(93)90018-R

FDIC. 2007. "Privatizing Deposit Insurance: Results of the 2006 Study." FDIC Quarterly, vol. 1, no. 2, pp. 23-32.

GAO (Government Accountability Office). 2017. "Private Deposit Insurance." Report to Congressional Committees, no. GAO-17-259, March.

House of Representatives. 1991a. "Closure of 45 Privately Insured Financial Institutions in Rhode Island: Hearing before the Subcommittee on General Oversight and Investigations of the Committee on Banking, Finance, and Urban Affairs." 102nd Cong., 1st sess.

—. 1991b. "Rhode Island Banking Crisis: Field Hearing before the Committee on Banking, Finance and Urban Affairs." 102nd Cong., 1st sess.

Lucas, Deborah. 2019. "Measuring the Cost of Bailouts." Annual Review of Financial Economics, vol. 11, pp. 85-108.

Nebraska. 1984. "Special Commonwealth Committee of the Eighty-Eighth Legislature, Second Session, of the State of Nebraska." Final Report.

Prosky, Melissa S. 2018. "Crisis of Confidence: Responding to the Rhode Island Credit Union Debacle.” Hassenfeld Institute for Public Leadership at Bryant University, May.

Richardson, Gary. 2013. "Banking Panics of 1930-31.” Federal Reserve History, November 22.

Rose, Jonathan D. 2015. “Old-Fashioned Deposit Runs.” Board of Governors of the Federal Reserve System, Finance and Economics Discussion Series 2015111. Available at https://doi.org/10.17016/FEDS.2015.111

Todd, Walker F. 1994. "Similarities and Dissimilarities in the Collapses of Three State-Chartered Private Deposit Insurance Funds." Federal Reserve Bank of Cleveland, Working Paper no. 9411, October. Available at https://doi. org/10.26509/frbc-wp-199411

Wood, Thomas B. 1992. "Special Legislation: The Nebraska Supreme Court Creates New Tests to Confuse an Old Issue: Haman v. Marsh, 237 Beb. 699, 467 N.W. 2d 836 (1991)." Nebraska Law Review, vol. 71, no. 1. 